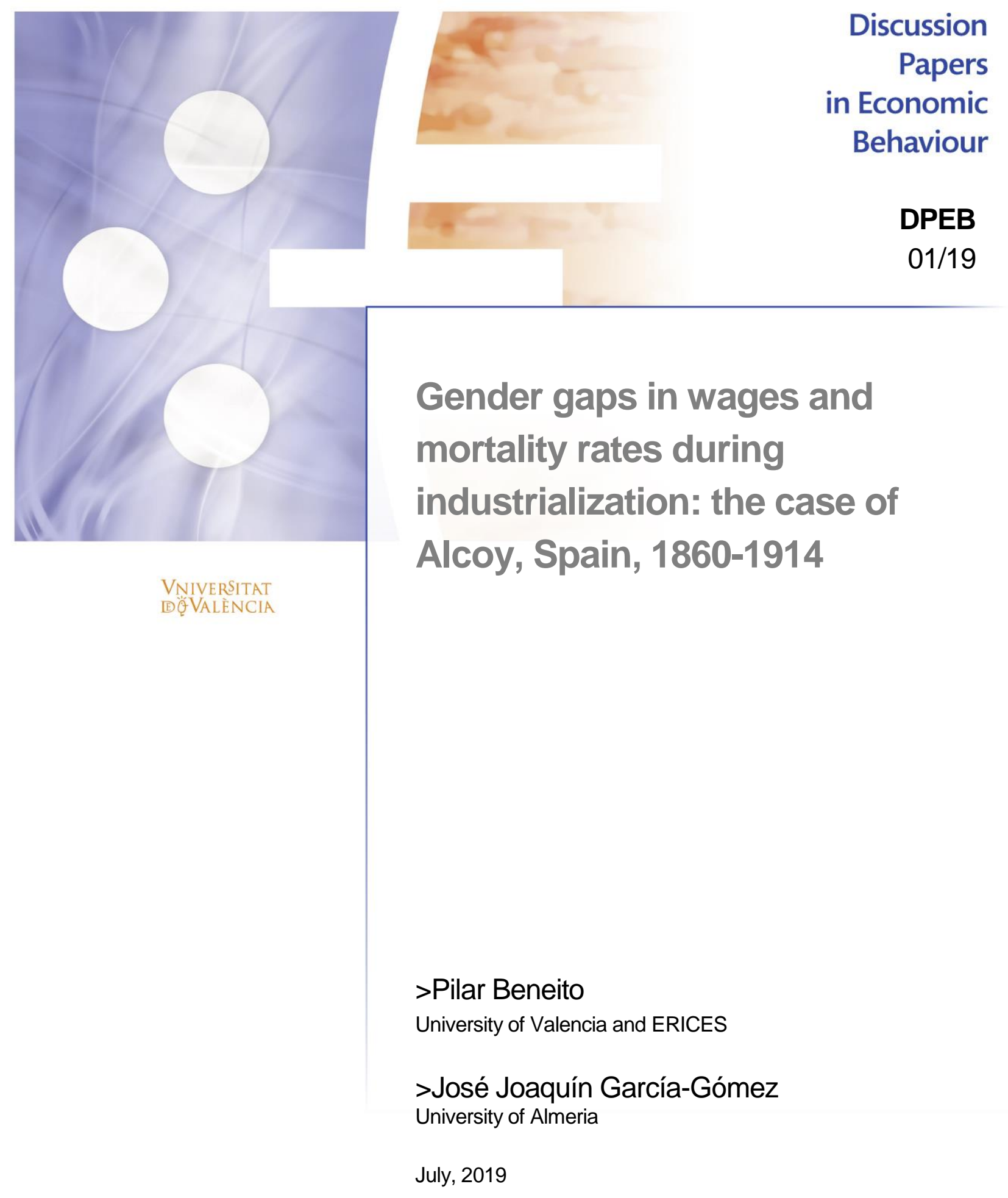




\title{
Gender gaps in wages and mortality rates during industrialization: the case of Alcoy, Spain, 1860-1914
}

\author{
Pilar Beneito ${ }^{\mathrm{a}}$ and José Joaquín García-Gómez
}

\begin{abstract}
What role did women play during industrialization? Interpretations of this key period of our history have been largely based on analyses of male work. In this paper, we offer evidence of the effects of women's involvement in the industrialization process that took place in Alcoy, Spain, over the period 1860-1914. Using data drawn from historical sources, we analyse labour-force participation rates and wage series for women and men in the textile industry and three other sectors of activity (education, health and low-skill services). We then connect the gender pay gaps with life expectancy indicators. Our results suggest that women's contribution to household income might have favoured the female life-expectancy advantage, an effect that seems to have been channelled through a reduction in the relative mortality rates of female infants and girls, at the expense of a higher mortality rate of working-age women.
\end{abstract}

Keywords: Female paid work, industrialization, gender wage gap, female mortality advantage.

JEL Codes: J16, J31, N33, O14

\footnotetext{
${ }^{a}$ University of Valencia, Spain, and ERI-CES

${ }^{\mathrm{b}}$ University of Almeria, Spain.
} 


\section{Introduction}

The Industrial Revolution opened up unprecedent opportunities for women to enter the labour market and carry out paid work. The shift of labour away from agriculture towards industry in many places, predominantly the textile industry - made the female population an abundant and dexterous labour force available to take on many of the tasks carried out in the factories. However, previous studies of industrialization have tended to overlook women's role in that process and instead have focused exclusively on the analysis of male work.

The participation of women in the labour market brought about substantial changes in their status in society. The interpretation of whether or not these changes were beneficial for women varies depending on whether historians take an optimistic or pessimistic perspective. According to the optimistic view (Neil McKendrick, 1974; Joyce Burnette, 1997; Jan de Vries, 2008), women would have enjoyed greater relevance and recognition in society because of their increased contribution to household income. According to the pessimistic view (Maxine Berg and Pat Hudson, 1992; Maxine Berg, 1993; Sara Horrell and Jane Humphries, 1995), women experienced great disadvantages during this period; indeed, they suffered a serious deterioration in their well-being due to the harsh working conditions. Hence, when studying the origin of female participation in the labour market, researchers have turned their attention to two particular aspects: on the one hand, the change in female earnings relative to male earnings brought about by the industrial revolution; and on the other hand, how women's participation in the labour force impacted their life conditions. These two aspects are at the centre of two classical, and recently renewed, lines of research: the analysis of gender wage gaps (Francine D. Blau and Lawrence M. Kahn, 2017), and the history and causes of female advantage in life expectancy (Claudia Goldin and Adriana LlerasMuney, 2018; Francisco Beltrán-Tapia and Domingo Gallego-Martínez 2018, 2017).

A better understanding of the origins of female labour market participation is essential to help interpret current gender gaps in wages and the evolution of female life conditions. In this paper, we aim to contribute in this direction by analysing data on labour market indicators and mortality rates in the Spanish city of Alcoy for the period 1860-1914. Following major data collection efforts drawing from historical archives and other sources, we firstly report 
and analyse female labour-force participation rates in Alcoy, which point to the substantial participation of women in the economic development of the city in that period. Secondly, and more importantly, we construct and analyse series of gender gaps in average daily wages paid in the city's key economic sector, the textile industry. We complement this information with gender wage gaps in three other sectors of activity of lesser importance in that period: education, health and low-skill services. Finally, we connect the labour-market gender gaps in industry with the so-called female advantage in life expectancy and gender gaps in mortality rates.

The city of Alcoy is considered representative of the Industrial Revolution in Spain, not only in contemporaneous reports of that period (for instance, Pascual Madoz, 1846, Real Academia de Medicina 1879; Ricardo Revenga, 1904), but also by modern historians (Jordi Nadal, 2003; Antonio Parejo, 2006). Thanks to its geographical location, Alcoy enjoyed the advantages of having hydraulic energy and wool from the sheep that were herded in the surrounding area. This endowment of factors helps explain the early development of a wool industry and the subsequent predominance of the textile industry in the process of industrialization that took place in this city over the $19^{\text {th }}$ century. Along with Sabadell and Tarrasa in Catalonia, Alcoy remained one of the leading Spanish textile producers until the later decades of the $20^{\text {th }}$ century. Given its historical importance, there are numerous studies of Alcoy's industrialization process (e.g. Joaquim Cuevas, 1999; Javier Puche, 2011; José J. García-Gómez, 2016; José J. García-Gómez and Antonio Escudero, 2018); however, none of these previous analyses have directly addressed the role of women in that process.

Previously, during the so-called 'Industrious Revolution' starting in the $17^{\text {th }}$ century, women and children had emerged as an abundant, cheap and dexterous labour force, extremely valuable in a textile sector that remained largely unmechanized at that point (Carmen Sarasúa, 2018). Gradually, women abandoned agricultural and domestic work and assumed a central role in the putting-out system that became common in the $18^{\text {th }}$ century (Maxine Berg, 1991; Joyce Burnette, 1999). In the putting-out system, merchants acquired raw materials that they distributed among rural households, where some of the family members, mainly women, took on the tasks of spinning and weaving the fabrics (Robert Allen, 2009). New technological developments and the mechanization of the tasks gave rise 
to the onset of industrialization, which centralized the work in the factory (David Landes, 1969; Joel Mokyr, 1990). Many workers in the putting-out system lost their jobs, but many others, particularly women, found jobs in many of the tasks carried out in the factories (Maxine Berg and Pat Hudson, 1992).

As the industrialization process became more established, women joined the labour force at a slower rate; thus, the evolution of women's labour-force participation during industrialization followed a U-shape curve (Carmen Sarasúa, 2018). Beyond statistical problems, such as the likely under-registration of women as workers in the official censuses (Jane Humphries and Carmen Sarasúa, 2012), women increasingly left the labour market as male earnings, and thus family income, rose (Maxine Berg, 1991; Jan de Vries 2008; Angelique Janssens, 1997).

Female labour-force participation would not start to increase again until female educational levels began to catch up with those of men (Claudia Goldin, 1995). Alternative explanations for this slowdown rely on the possible effects of technological changes, which would have made men's physical strength a more valuable asset in the increasingly mechanized factories (Joyce Burnette, 1997, 2008). Along with this, there was a variety of institutional and social discriminatory practices, as well as the actions of the male-dominated unions (Angela V. John, 1983; Gertjan de Groot, 2001), which were eventually reflected in labour legislation in many European countries restricting the work of women. Examples of this include the constraints on women working in the mines and factories of Great Britain (1842), France (1874), Belgium (1889), Germany (1900), Italy (1907), Spain $(1897,1908)$ and Greece (1912), among other. ${ }^{1}$

In order to go a step further in the analysis of the female contribution, it is necessary to quantify women's earnings as compared to men's. In this regard, the scarcity of data and

\footnotetext{
${ }^{1}$ An extensive list of the social legislation in Europe can be found in the convention adopted at the General Conference of the International Labour Organization, concerning the Employment of Women on Underground Work in Mines of all kinds (Geneva, 1933), pp. 9-22.
} 
official statistics in the currently existing registries impose important limitations on the analysis (Jane Humphries and Carmen Sarasúa, 2012). Some of these scarce data reveal that, for example, female wages in Great Britain were around $60 \%$ of male wages in the preindustrialization period, with this figure dropping to around $35 \%-50 \%$ during the expansion of industrialization (Joyce Burnette 1997, 2008). During the French industrialization, female wages were around $50 \%$ of male wages in the textile industry (Donald Cox and John Vincent Nye 1989). The corresponding figure for Germany is around 50\% (Gerhard Bry 1960), around 58\%-65\% for Sweden (Gosta Bagge, Erik Lundberg and Ingvar Svennilson, 1933), and between $42 \%$ and $66 \%$ in the United States (Claudia Goldin, 1990). The available data for Spain indicate that women's earnings during the $19^{\text {th }}$ and mid- $20^{\text {th }}$ centuries range from $40 \%$ to $70 \%$ of men's earnings (Álvaro Soto Carmona, 1989; Pedro Pérez Castroviejo, 1992; Enriqueta Camps, 1995; Raimon Soler, 1997; Cristina Borderías and Pilar López, 2001; Luisa Muñoz, 2012; Margarita Vilar, 2014).

Therefore, the critical role played by women during industrialization is beyond doubt, as is the fact that discrimination against women in the labour market started as soon as mechanization eliminated jobs and male wages increased. But how did the participation of women in the labour market affect the standard of living in that period of history and, in particular, gender differences in these living conditions?

In contrast to the gender earning gap in favour of men, many studies have shown a female advantage in mortality rates and life expectancy in many parts of the world (Anna Barford et al., 2006; Steven Austad, 2006; Hiram Beltrán-Sánchez et al., 2015; Mark Cullen et al., 2016). A recent study by Claudia Goldin and Adriana Lleras-Muney (2018) reports that this advantage in favour of women has not been constant over time; indeed, only Swedish women seemed to live longer than their male counterparts before the mid-19 $9^{\text {th }}$ century. This gap appeared around the mid- $19^{\text {th }}$ century in Britain and France and in the late $19^{\text {th }}$ century in the United States.

Two countervailing effects on life conditions followed female participation in paid work during industrialization. On the one hand, as the level of household income increased 
thanks to women's greater contribution, household members would have been able to enjoy better nutrition and sanitary conditions. However, this income-enhancing effect could have been undermined by the harsh working conditions faced by women as their participation in the labour market intensified.

Even if we accept that women's participation in the labour market would have resulted in significant impacts in terms of their households' standard of living, it remains unclear why this would affect female and male life expectancy differently. In this regard, the recent works by Beltrán and Gallego-Martínez (2017 and 2018) about the "missing girls" anomaly in Spain in the $19^{\text {th }}$ century, strongly suggest that girls suffered from discrimination and fatal neglect early in life, that is, that parents treated their sons and daughters differently in terms of food and care. The authors specifically mention "the presence of wage labour opportunities for women (...)" (op. cit. 2018, p. 1) as a possible source of beneficial effects in girls' survival.

Contrary to the hypothesis of girls being discriminated against inside their households, Claudia Goldin and Adriana Lleras-Muney (2018) find no evidence that differences in mortality were due to differences in nutrition by gender. Furthermore, they review evidence from other sources that equally fail to support the hypothesis of an unequal allocation of resources between boys and girls within the household (see Claudia Goldin and Adriana Lleras-Muney, 2018, for a complete list of references therein). Using data on causes of deaths in Massachusetts from 1887 to around 1930, they argue instead that females between the ages of 5 and 25 had a disadvantage in mortality from infectious diseases; when infectious disease prevalence fell-according to the authors, largely due to public health interventions in the early $20^{\text {th }}$ century-women benefited relatively more than men. However, as it seems to have happended with the incidence of the infectious deseases, the higher spending levels on nutrition and health within the household, even if equally distributed between male and female members, might have had different impacts depending on gender.

Thus, the analysis of the possible channels through which the reduction in gender wage gaps could have ended up affecting the relative life expectancy of men and women is certainly complex. While we are aware of the inherent difficulties of the analysis, in the last 
part of the paper we attempt to contribute to this debate by connecting the observed gender gaps in wages and labour-force participation rates with the gaps in life expectancy and mortality rates. To this end, we estimate the impact of gender wage gaps on gender gaps in mortality at different ages, while controlling for the probable joint impact of public health expenditures.

In summary, we analyse gender inequalities in both earnings and life expectancy using the excellent natural experiment provided by Alcoy during the first Industrial Revolution; moreover, we explore the relationship between these gaps. Our work contributes to the existing literature on at least three fronts. Firstly, we present unpublished series of female labour-force participation rates in industry in Alcoy covering the period 1860-1914, which allows us to describe the role played by women in the workforce at that time. Secondly, we construct measures of gender wage gaps and analyse these gaps in the textile industry, along with gender wage gaps in the main occupations in education, health and low-skill services. We analyse the periods of convergence and divergence in these wage gaps, both at a descriptive level and econometrically controlling for the influence of other variables such as gender gaps in literacy rates over the period or public expenditures on education and health. Thirdly, we construct a measure of life expectancy at birth and mortality rates separately for men and women over the period and examine the link between the gender wage gaps in industry and these indicators of life conditions. In doing so, we qualify existing evidence by addressing the relationship between gender wage gaps and gender mortality differences for different age intervals, while controlling for important covariates such as labour-force participation rates or public health expenditure.

The rest of the paper is structured as follows. In Section 2 we present the sources of data used and detail the methodology used to construct the series. In Section 3, we describe the social and economic context of Alcoy at that time, on the basis of the obtained female labour-force participation rates and complementary information, and compare our data with other available sources. Section 4 is devoted to the descriptive and econometric analysis of the gender wage gaps, while in Section 5 we present the econometric estimation of the relationship between gender wage gaps and mortality rates. Finally, in Section 6 we present the conclusions drawn from the analysis. 


\section{Sources of data and series construction.}

The first empirical contribution of our work lies in the arduous data compilation process carried out in order to construct the wage series by gender and across four economic sectors in Alcoy during the industrialization period spanning from 1860 to 1914. These four sectors are the textile industry, which is by far the most important and representative sector of the economy of Alcoy in that period; the education sector (schoolteachers); the health sector (doctors and midwifes); and the low-skill service sector (workers such as janitors, gardeners, or maids). These four sectors were selected on the basis of both data availability and the fact that they represent the most important sectors in Alcoy during industrialization, given that the agricultural sector did not play a relevant role in this city and virtually no women worked in it. The period of time for which data is available both for men and women and for the four abovementioned economic sectors runs from 1860 to 1914. Thus, our analysis is restricted to that period of time.

Besides the series of wages, throughout our analysis we present and work with data series of other important economic and demographic variables. On the one hand, along with life expectancy and mortality rates differentiated by gender, we construct genderdifferentiated measures of labour-force participation rates and literacy rates, all of which will be used in the regression analysis below and connected with the wage gap variables. On the other hand, we also gathered data on public spending that the municipality of Alcoy allocated to health and education during those years. These expenditures will be used as covariates in the econometric estimation to control for the potentially relevant effect of state contribution on the relationships under study.

In this section, we detail the different sources of information used and how the variables of the analysis have been constructed. We leave the analysis of these variables for the sections that follow. 
Labour-Force Participation Rates. The data used to construct the labour-force participation rates by gender come from several sources of official statistics collected at different times by the municipal administration of Alcoy, as required by Spain's central government. They are:

- In 1803: “Interrogatorio sobre las artes, oficios, fábricas de Alcoy”, (Survey of the arts, trades, and factories in Alcoy).

- In 1856: “Estadística industrial”, (Industrial statistics)

- In 1884: “Información oral y escrita practicada por la Comisión de Reformas Sociales en la provincia de Alicante", (Oral and written information collected by the Committee for Social Reforms in the province of Alicante).

- In 1914: “Estadística obrera en 25 de octubre de 1914”, (Labour statistics on 25 th October 1914).

These sources provide the number of working men and women in the city over the years, which we divide by the male and female working-age population, respectively, taken from the official censuses carried out in Alcoy from 1857 onwards (we have considered working age to cover the range from 10 to 70 years old, given the lack of an official definition of working age in that period).

Wages in the textile industry. The industrial wages refer to the textile industry, which was the most important industrial segment in the city. The sources used in this case are:

- From 1860 to 1890: the minute books from the Real Fábrica de Paños de Alcoy (an institution which emerged from the early association of textile manufacturers created in the $16^{\text {th }}$ century), preserved in its Archive (Archive of the Royal Factory of Fabrics of Alcoy). These books contain information about contracts as well as technical, political, commercial and labour issues faced by the manufacturers, including information on average wages paid by gender and year in the city's textile factories.

- From 1890 onwards the data come from the Libros-Padrones de Cédulas Personales (Census Books of Identity Cards). These identity cards, created in 1854, were the basis for the personal income tax. It was compulsory for the inhabitants of Alcoy to apply for a card and subsequently renew it. In the renewal documents, the applicant 
was asked about their job and wage; this information was not compulsory and was thus voluntarily provided. The data we have collected on wages in the textile industry have then been averaged per year and gender (over the whole period, we examined a total of around five hundred cards for men, and around two hundred for women).

The data we have compiled yields possibly one of the most important salary databases for that period in Spain, particularly considering the gender disaggregation of the wages.

Wages in the education sector (schoolteachers), in the health sector and in the low-skill service sector: These wages were paid by the municipality of Alcoy, and the source of information is the officially approved municipal budgets, where the municipality specified the wages paid to the public workers. In particular:

- In the case of the education sector, the wages correspond to the same job (schoolteacher) for both men and women.

- In the case of the health sector, the wages correspond to different jobs: men were doctors and surgeons, while women were midwives (many of whom also helped as nurses in Alcoy's hospital).

- In the case of the low-skill service sector, the information gathered corresponds to the wages paid to low-skill workers in the hospital, school and city hall, who provided their services as gardeners, cleaners, cooks, caretakers, etc.

The number of teachers per year in Alcoy's municipal school did not exceed 6 men and 4 women. As for the hospital, the available data for men and women refer to around 13 doctors and to 20 midwives/nurses per year, respectively. Thus, these wages cannot be considered important drivers of the economic level of the city in that period; however, we consider them highly interesting from the point of view of the comparison with the industrial wage gaps, and also for historical reasons since such data are fairly rare for this period.

In all cases, the data refer to daily nominal wages in each sector by gender and year. They have been deflated to get real wages using the cost-of-living index estimated in José J. 
García-Gómez and Antonio Escudero (2018) for the city of Alcoy and for all the years in the period 1860-1914. ${ }^{2}$ Thus, our variables are sector-year measures of male and female wages in real pesetas per day. As a result, we end up with measures for 440 wages (4 sectors, 55 years, 2 genders).

Mortality rates by gender: Female and male mortality rate series have been constructed using the data available in Ángel Beneito (1993) for the period 1860-1876, the death registry books preserved in the Registro Civil (civil registry) since the 1870s, the official population censuses and statistics on the Movimiento Natural de la Población (Natural Population Movement) from the Instituto Nacional de Estadística (the Spanish National Statistics Institute). In particular, this research draws on the available censuses for $1860,1877,1887$, 1897, 1900 and 1910. From this information we have built mortality tables by gender and age cohorts following an actuarial model (Enrique Vázquez, Francisco Caamaño, John Silvi and Anne Roca, 2003). Mortality rates are defined as the ratio between the number of deaths of people of a given gender and age in a year, and the total population of the same gender and age in that year. The rates are constructed for the census years, and interpolated for the years in between. In the case of infants, we have complemented the census information with data on the number of births each year (taken from Ángel Beneito, 1993) to correct for the under-registration of infants under one year of age, which was common in that period.

Public expenditures on health and education (real, per-capita), and literacy rates: The series of public expenditure on health and education between 1860 and 1914 come from the officially approved budgets of the municipality of Alcoy, available at the Archivo Municipal de Alcoy. They are real per-capita measures (divided by the number of inhabitants of Alcoy and deflated as described above for wages). Finally, literacy rates by gender come from the

\footnotetext{
2 The price index is a Laspeyres type index based on more than 36,000 retail prices for food, energy, clothing and rent in Alcoy. These prices come from the logbooks of the Archivo Municipal de Alcoy (Municipal Archive of Alcoy), the Archivo Histórico del Instituto Nacional de Estadística en la Provincia de Alicante (Historical Archive of the National Statistics Institute in the Province of Alicante), as well as from the accounting books of the hospital of Alcoy. The basket of consumer goods was defined and updated in 5 years: 1852, 1868, 1884, 1897 and 1912. For more methodological details, see García-Gómez and Escudero (2018), op.cit.
} 
official censuses and statistics available at the Archivo Municipal de Alcoy and the Instituto Nacional de Estadística.

Before we undertake the analysis of the gender wage gaps and the gender mortality gaps in Sections 4 and 5, in the next section we offer a general description of the economic and social context of Alcoy during the period 1860-1914, based on the rest of information collected (male and female labour-force participation rates, public expenditures and literacy rates).

\section{Economic and social context.}

Alcoy is a city located in the South-East of Spain, in the Valencian Community (province of Alicante). The city's population is nearly 60,000 as of 2018, and was around 25,000 in 1860 . Thanks to Alcoy's geographical location, the city enjoyed the advantage of having hydraulic energy and wool from the sheep that were herded in the surrounding area. However, the lack of cultivable land due to its mountainous, arid environment meant that there was no substantial agricultural sector in Alcoy, with farming tasks generally reserved for men. The carding and spinning of wool was done in peasants' households located out of town, while the beating, weaving and dying tasks were undertaken in the city by craftsmen organized in guilds.

In the late $18^{\text {th }}$ century, high transaction costs forced traders to abandon the puttingout system and concentrate production in factories with hydraulic machinery (Lluís Torró, 1994). Thanks to its entrepreneurs, trained workforce and hydropower, as well as the progressive mechanization of the tasks in the factories, by the mid-19th century Alcoy had become the second-largest wool producer in Spain, behind the area of Sabadell and Tarrasa in Catalonia. Indeed, it remained one of the leading producers of Spanish textiles until the 
late $20^{\text {th }}$ century. ${ }^{3}$ In addition, taking advantage of synergies with the textile industry, a paper industry developed in the city, and by 1856 it had become Spain's second-largest producer of paper (Enrique Cerdá, 1967, and Jordi Nadal, 2003). The third most important industrial sector in Alcoy during this period was the metallurgical industry (Rafael Aracil and Mario García, 1974).

The development of the textile industry opened up unprecedent opportunities for women to enter the labour market, whether working inside the factories or at home. There are significantly more data on the labour-force participation and wages of women in industry, as well as related information and reports. The reports of the Comisión de Reformas Sociales (Committee for Social Reforms, 1985 [1889-1893]) constitute a valuable source of informal statements that also shed light on the social and economic environment of the city of Alcoy in that period.

According to one of the available reports, that of the Weavers Society in 1884, (p. 119), "women search for employment outside their home out of sheer necessity, because their husbands' wages do not suffice to meet the needs of the family. This, besides being morally detrimental due to the bad manners of many of those employed in the workplace and the neglect of young children, notably undermines the work of men in several jobs because women occupy men's posts while being paid much less, which makes manufacturers prefer women to men". The report also adds that: "In many cases the woman of Alcoy works in her own home (...). In the industry, they undertake tasks such as the selection of rags (...) and, as far as possible, the trend should be to banish women from factories, replacing them with men, and relegating them to their home, which is their true place”, (p. 44). These testimonies provide evidence that women's labour-force participation was understood as justified only in cases of necessity, when they had to contribute to the household earnings. Moreover, it was

${ }^{3}$ Given the lack of data on the Spanish production of wool in the $19^{\text {th }}$ century, some authors have used tax data to infer the level of production in different locations in Spain. These data suggest that in 1856, around $30 \%$ of all Spanish wool production came from Terrassa and Sabadell, in Catalonia, and 10\% from Alcoy (Jordi Nadal 2003). 
expected that this participation should eventually be eliminated to avoid competition with men.

Another of the informants in the report states that "unlike what happened with men, women's working hours are not regulated; women regularly work from dawn to dusk, without fixed hours" and concludes by saying that "women's bad working conditions lead to doleful consequences and it is essential to avoid them at all costs", (p. 45). According to another informant, "women in this industry have their own special tasks, different from men's, and they work fewer hours (9 instead of 11)", (p. 103).

Hence, our constructed measures of daily wages could well be measuring different payments to men and women both because they performed different tasks within the production process and because of differences in their daily working-hours. Thus, our indicators of gender wage gaps should be taken as gaps in earnings per day, and we acknowledge the limitation of our data in this regard as an indicator of discrimination in the strictest sense (i.e., different pay for performing the same task for the same amount of time).

To provide a better idea of how important the labour-force participation of women was in this context, we present in Table 1 some figures on male and female labour-force participation rates in Alcoy during the period of analysis. ${ }^{4}$ As we can see, the female labourforce participation rates in the city were notably high during the first decades of the industrialization process, peaking at $63.40 \%$ during the 1880 s. As some authors have pointed out, high female labour-force participation rates were observed during recessionary cycles, in sectors and places that specialized in low-quality products manufactured using low-wage work, and in regions predominated by sectors in which the bulk of the work consisted of tasks traditionally considered women's work, such as the textile industry (Carlos Arenas, 2003).

\footnotetext{
${ }^{4}$ Female labour-force participation rates were probably under-recorded by official bodies, especially from the last quarter of the $19^{\text {th }}$ century (see, e.g., Jane Humphries and Carmen Sarasúa, 2012).
} 
Table 1.

Labour-Force Participation Rates, by Gender. Alcoy, 1860-1914

\begin{tabular}{lcc}
\hline \hline Decades & Men $(\%)$ & Women (\%) \\
\hline $1860-1869$ & 61.24 & $47.58^{* * *}$ \\
$1870-1879$ & 61.54 & $56.60^{* * *}$ \\
$1880-1889$ & 61.83 & $63.40^{* *}$ \\
$1890-1899$ & 62.12 & $53.20^{* * *}$ \\
$1900-1914$ & 62.50 & $48.80^{* * *}$ \\
\hline Industry & 61.90 & $51.30^{* * *}$ \\
\hline & Source: Own elaboration. Differences significant at: $1 \% * * * ; 5 \% * *$
\end{tabular}

A noticeable decline in women's labour-force participation rates occurred towards the end of the $19^{\text {th }}$ century and the early years of the $20^{\text {th }}$ century, dropping to a value of $48.8 \%$ in the first decade of the $20^{\text {th }}$ century (around $35 \%$ in 1914). This reduction can be explained by several forces that intensified during the two last decades of the $19^{\text {th }}$ century. On the one hand, the control exercised by the male workforce in the trade unions, who saw women as competitors driving wages downwards, led to the expulsion of many women from the factories. Along with this, women were pressured to return to their households by the socalled social hygienists and anarchists, for reasons relating to sexual control over women, childcare, improved hygiene and nutrition of the family members. ${ }^{5}$ Simultaneously, the technological and organizational modernization taking place in industry in the 1880s promoted changes in the legislation targeted at blocking women from working in many activities. As a result, in Alcoy, as in many other regions during the first Industrial Revolution, the female labour-force participation rate began to decline as its production system became more modernized and the economic level of the city started to rise rapidly in

\footnotetext{
5 The anarchist "Petroleum Revolution" in 1973 was linked to the Spanish cantonalist movement that arose during the First Republic (1873-1974). Events in Alcoy began with more than 10,000 workers taking part in a demonstration to demand higher salaries and shorter workdays. The factory owners' refusal to meet their demands and the intervention of the police to contain the insurrection resulted in 16 deaths and the burning down of several factories.
} 
1880. It was at this time that the stereotypical image of the male breadwinner started to become more widespread (Pilar Pérez-Fuentes 1993; Enriqueta Camps, 1995).

To contextualize the female labour-force participation rates of Alcoy during the analysed period, we present in Table 2 some corresponding figures for industries in other European regions during the $19^{\text {th }}$ century. The female labour-force participation rates range from $36 \%$ in 1834 in the spinning industry of the French region of Seine, to above $70 \%$ in the dressmaking sector and in the wool industry of Verviers in the1850's. The figures are somewhat lower for the paper and shoemaking industries in Paris towards 1850, or at the beginning of the $20^{\text {th }}$ century in the wool industry of the Belgian region of Ghent. Available figures for other industries and regions (not reported in the table) document female labourforce participation rates of around $40 \%$ in 1850 in the industrially-pioneering Great Britain, 60\% in Argentina in 1869 (Donna Guy, 1981), and 45\% in France in 1911 (Alain Dewerpe, 1996). Hence, the female labour force-participation rates in Alcoy during those decades were quite closely in line with those observed in other European regions as industrialization became established over the $19^{\text {th }}$ century, at least in the textile and similar industries.

Towards the end of the $19^{\text {th }}$ century, female labour-force participation rates declined in many industrial cities around Europe, including Alcoy, falling to rates of around 30 to $35 \%$ in textile cities such as Odense in Denmark (55\% in $1872,34 \%$ in 1910$)$ or Twente in the Netherlands (Sara Horrell and Jane Humphries, 1997; Cristina Borderías and Pilar López, 2001). In Argentina, female labour-force participation rates dropped to 30\% in 1895 (Donna Guy, 1981). Female labour-force participation in developed countries remained around these levels until the 1990s.

Alongside the profound changes of that period in the economic, social and labourmarket conditions of the people of Alcoy, significant demographic growth was registered from the 1880s onwards. This population rise was in response to the economic expansion 
Table 2. Wages by Gender across Sectors.

Alcoy, 1860-1914

\begin{tabular}{|c|c|c|c|}
\hline \multicolumn{4}{|l|}{ Textile Industry } \\
\hline Decades & Male & Female & Female-male ratios \\
\hline $1860-1869$ & 2.66 & $1.87^{* * *}$ & $70.39 \%$ \\
\hline $1870-1879$ & 3.06 & $2.10^{* * *}$ & $68.60 \%$ \\
\hline $1880-1889$ & 3.55 & $1.55^{* * *}$ & $43.53 \%$ \\
\hline $1890-1899$ & 3.92 & $2.50^{* * *}$ & $63.78 \%$ \\
\hline $1900-1914$ & 2.98 & $2.01 * * *$ & $67.27 \%$ \\
\hline \multicolumn{4}{|c|}{ Whole period $1860-1914$, by sector } \\
\hline Industry & 3.21 & $2.00 * * *$ & $62.25 \%$ \\
\hline Education & 6.63 & $5.93^{* * *}$ & $89.40 \%$ \\
\hline Health & 4.35 & $0.75^{* * *}$ & $17.12 \%$ \\
\hline Low-skill services & 2.07 & $1.12^{* * *}$ & $54.20 \%$ \\
\hline All sectors and period & 4.21 & $2.74 * * *$ & $65.17 \%$ \\
\hline
\end{tabular}

that was fully underway in that decade, but this economic development happened in a fairly uncontrolled way that accentuated the negative consequences of such accelerated industrialization and the accompanying chaotic urbanization (Ricardo Revenga, 1904). State intervention was crucial to help alleviate these negative externalities, particularly the public health reform undertaken in Alcoy in the last years of the $19^{\text {th }}$ century (José J. García-Gómez and Salvador Salort, 2014). The progress made in public health spending was a salient feature of the period.

Figure 1 shows the evolution of public sector intervention in terms of spending on both health and education. We also show literacy rates by gender in the city over the period, 
Figure 1. Public Expenditures and Literacy Rates. Alcoy, 1860 - 1914
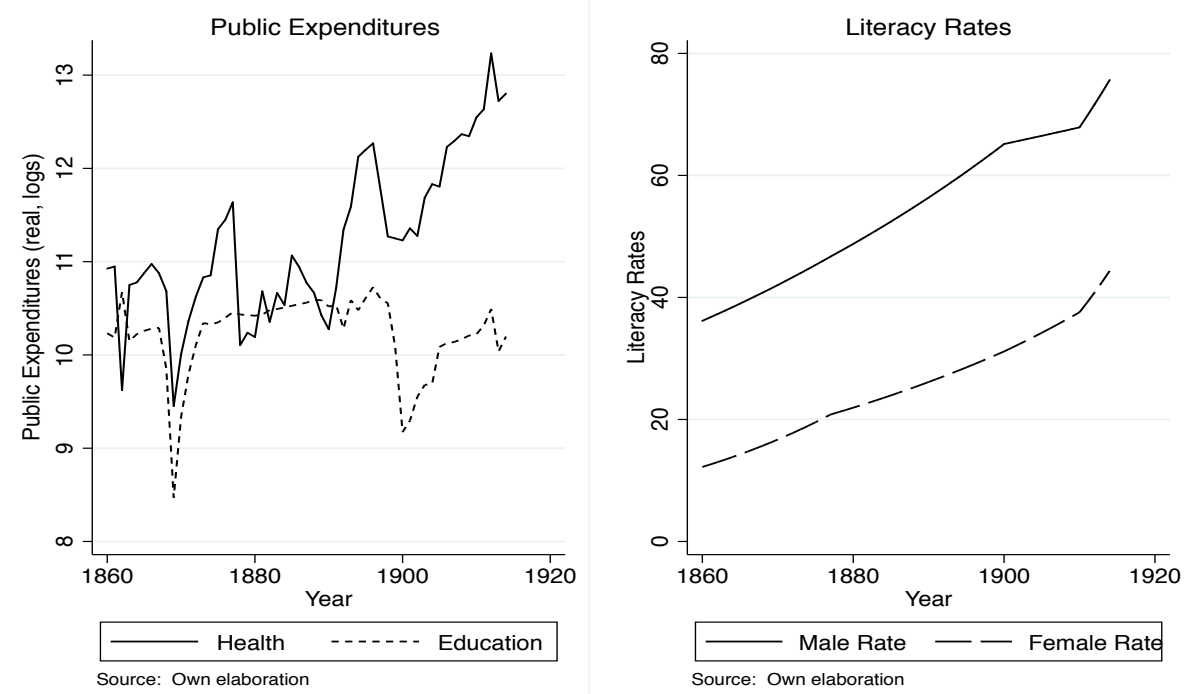

to convey a more complete picture of the evolution of living standards for Alcoy's population, other than in terms of wages and labour-force participation. A huge increase in public expenditures on health is evident from the mid-1880s onwards. Literacy rates also rose during the period, with male literacy rates rising from $38.75 \%$ in 1860 to $68.14 \%$ in 1914 , and female rates changing from $14.11 \%$ to $36.25 \%$ over the same period. Hence, a remarkable difference between male and female literacy rates was evident and, although there was a positive and rapid change in these rates over the period, the gap between men and women widened even more.

In the next two sections we provide more detail on the data concerning wages and the related gender gap, as well as their connection with our measures of life expectancy and gender mortality gaps.

\section{Gender wage gaps: differences across sectors and years.}

In this section, we first present some basic descriptives and graphs to illustrate the differences in real wages by gender across sectors and over time. Then, we detail our regression results to ascertain the statistical significance of the main differences identified, and to examine the explanatory power of both gender differences in labour-force participation rates and literacy rates for the wage gaps. 
Table 2 displays the levels of the real wages for males and females across sectors and time, showing the statistical significance of the differences in all cases. In the upper half of the table, we show the average wages in the textile industry, which at that time was a key economic activity in Alcoy. The average wage per day for males ranged from 2.66 pesetas per day during the 1860 s to around 3 pesetas in the first decade of the $20^{\text {th }}$ century, following a sort of inverted U-shape with lower values at the beginning and end of the period and higher average wages in the intervening decades. The average wage for women was clearly below that for men over the whole period, with women's wages at around 70\% of men's average wages at the beginning and end of the period, and as low as $43.5 \%$ during the 1880 s. Hence, these initial results suggest that the gender earning gap in industry appears to be higher in the mid-1880s and the 1890s, coinciding with the intensification of the industrialization process in the city and when male wages, according to the figures in the table, reached their highest values.

Among other causes, these gender wage gaps reflect an appreciable gender segregation across tasks in this industry, where women used to work as cutters, seamstresses, spinners or selecting stuffing, while men worked as weavers, dyers and machine operators. In other words, women mainly held the lowest-paid jobs, and as a result were clearly penalized in the wage distribution. Nonetheless, we can find some women performing the same tasks as men, although it was not commonplace. For example, some women worked in weaving with daily wages slightly below $50 \%$ of the wage earned by men.

The bottom half of Table 2 displays the average wages and gender differences across sectors for the whole period and for the four sectors of activity considered. Men earned the highest wages in the high-skill occupations of the service sectors, that is, in the health sector (doctors) and in the education sector (schoolteachers), followed by wages in industry and, finally, in the low-skill service sector (janitors, caretakers or gardeners). However, women's highest wages were earned in the education sector, while their lowest wages were earned in the health sector. The health sector was probably the one affected by the highest and most persistent degree of gender segregation across occupations and time: doctors were always men, and women always worked as midwives or nurses. This would indicate the existence 
Table 3. Gender Wage Gaps in several factories of Spain, 1856-1915

\begin{tabular}{lcc}
\hline \hline & & \\
Factory & Year & Women wage / Men wage \\
\hline Barcelona (all the city) $^{\mathrm{a}}$ & 1856 & $52 \%$ \\
Santa Ana de Bolueta (Vizcaya) $^{\mathrm{b}}$ & 1877 & $48 \%$ \\
Santa Ana de Bolueta (Vizcaya) & 1889 & $45 \%$ \\
Santa Ana de Bolueta (Vizcaya) & 1897 & $49 \%$ \\
Colonia Sedó (Barcelona) & $1901-1919$ & $77 \%$ \\
La Rambla (Barcelona) $^{\mathrm{c}}$ & $1901-1919$ & $62 \%$ \\
La España Industrial (Barcelona) $^{\mathrm{c}}$ & $1901-1919$ & $55 \%$ \\
Altos Hornos de Vizcaya (Vizcaya) $^{\mathrm{d}}$ & $1901-1915$ & $38 \%$ \\
\hline
\end{tabular}

Sources: ${ }^{a}$ Cristina Borderías and Pilar López Guallar, 2001; ${ }^{\mathrm{b}}$ Pedro Pérez Castroviejo, 1992; ${ }^{\mathrm{c}}$ Vilar 2014, op. cit. from Raimon Soler 1997, Enriqueta Camps 1995 and Álvaro Soto Carmona 1989. dPérez Castroviejo, 1992, op. cit.

of a "glass ceiling" during industrialization, with women not having access to the best paid occupations in the service sector. ${ }^{6}$ Finally, we want to emphasize the relatively good position of women in education, with female teachers being greatly appreciated in this sector, a situation that has been historically acknowledged (e.g., Sónsoles San Román 2000). In fact, as our analysis below will show, women in this sector even earned more than men during certain parts of the period.

Figures 2 and 3 display the evolution of the gender wage gaps over the period of analysis. First, in Figure 2 we plot the (log of) male and female wages separately, as well as the (log of) the male-to-female wage ratio. Male wages were above female wages during the whole period, with the gap widening appreciably up to the mid-1880s and decreasing later on until around 1905. In the later years of the observed period, the gap started to increase considerably again, so that by 1914 the gap had once again reached the levels of the 1880 s.

Second, in Figure 3 we display the (log of) male-to-female wage ratios in all four sectors considered. The first observation to be made is the appreciable difference in wage

\footnotetext{
6 There were no women at all working in other high-paid jobs within the service sector, such as engineering.
} 
Figure 2. Gender Wage Gaps in the Textile Industry, Alcoy, 1860-1914

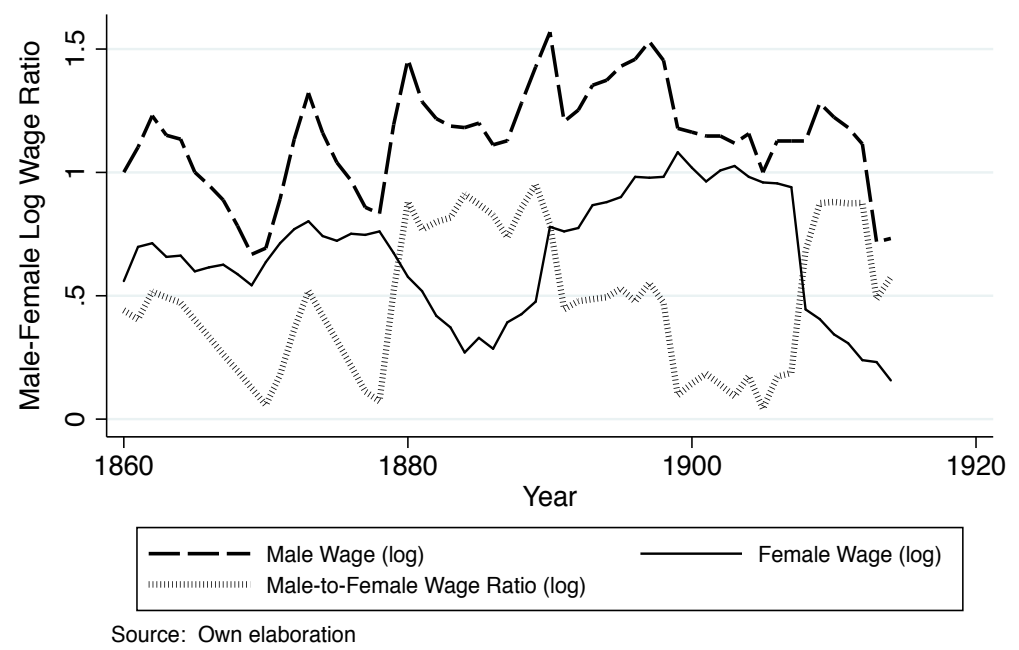

gaps across sectors, with the health sector and the low-skill service sector exhibiting the highest gaps, with a clear inverted U-shape up to the mid-1880s. In general, from then onwards the wage gaps started to decline in all sectors, with the exception of the low-skill sector, where we see an upward trend in the size of the gap until the end of the century. In the early years of the $20^{\text {th }}$ century, the wage gaps started to increase again. By 1914 , the wage gap in industry had risen to the levels of the gaps in low-skill services.

The education sector merits special attention as the gaps remained largely unchanged over almost the entire period. To be more precise, the available data shows that male schoolteachers earned more than their female counterparts up to the mid-1880s (log of the male-to-female ratios above 0), but the gap improved slightly in favour of women from then onwards. In Spain, this sector received a vital boost with the Moyano Law of 1857, a central government law which made elementary education compulsory, and also aimed to promote middle-level and higher education. The enhanced demand for teachers from then onwards meant that women enjoyed a relatively good position in relation to men, especially when compared to other sectors of activity.

Although there is scarce literature and available documentation on wages by gender in Spain during the analysed period, in Table 3 we offer some figures that might serve as a 
Figure 3. Gender Wage Gaps by Sector, Alcoy, 1860-1914

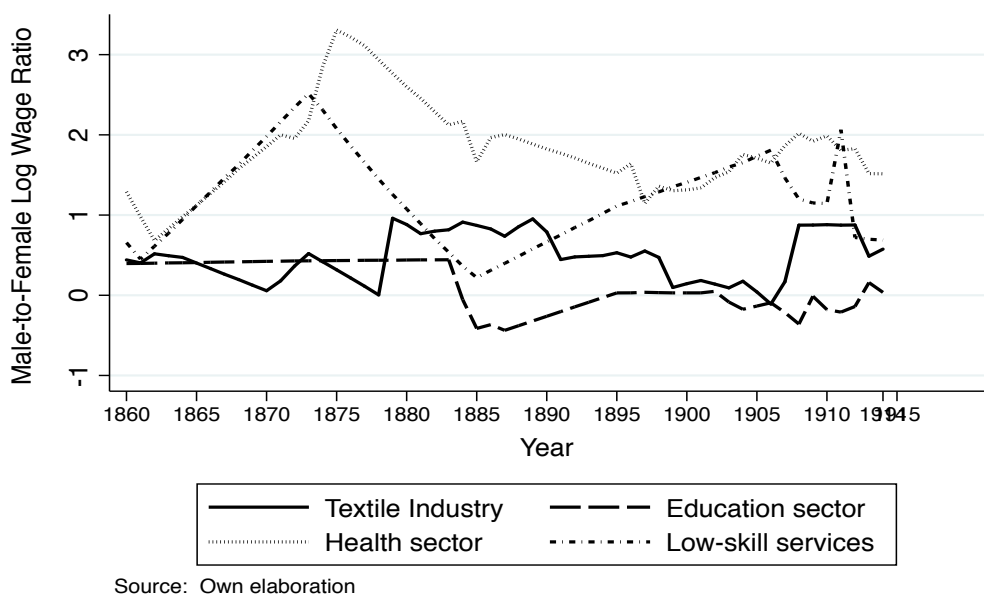

reference. These figures correspond to factories in the textile and metal sectors. The highest wages earned by women were in the textile factory of Colonia Sedó in Barcelona: in the early years of the $20^{\text {th }}$ century (from 1901 to 1919), women's wages there were equivalent to $77 \%$ of those earned by men. The lowest female relative wage corresponds to the steel factory of Santa Ana de Bolueta in Vizcaya, with female-to-male ratios of below $50 \%$ in the last quarter of the $19^{\text {th }}$ century, and Altos Hornos de Vizcaya with ratios around $38 \%$ over those years. The figures for the textile industry in Barcelona are quite closely in line with the wage gaps observed in Alcoy.

In order to give a more accurate account of the sign, magnitude and statistical significance of the observed differences, we now present some regression results in Tables 4 and 5. Before proceeding with the estimation, we have applied the augmented Dickey-Fuller tests of unit root to the gender wage gap series. These results are displayed at the bottom of Table 4, and they allow us to rule out concerns of unit roots in the wage gap series in all the four sectors considered at conventional levels of significance.

Columns 1 to 5 in Table 4 show the estimates for different sectors and periods, first without and then with gender gaps in literacy rates and in labour-force participation rates, as 
Table 4. Gender Wage Gaps (Alcoy. 1860-1914)

Dep. Variable: $\log \left(\right.$ Wage male $^{-}$Wage $\mathrm{W}^{\text {female }}$ )

\begin{tabular}{|c|c|c|c|c|c|}
\hline & $(1)$ & $(2)$ & (3) & $(4)$ & $(5)$ \\
\hline Education sector & $\begin{array}{c}-0.360 * * * \\
(0.058)\end{array}$ & $\begin{array}{c}0.004 \\
(0.054)\end{array}$ & $\begin{array}{c}0.004 \\
(0.100)\end{array}$ & $\begin{array}{c}0.004 \\
(0.101)\end{array}$ & $\begin{array}{c}0.004 \\
(0.103)\end{array}$ \\
\hline Health sector & $\begin{array}{c}1.345^{* * * *} \\
(0.089)\end{array}$ & $\begin{array}{c}1.560 * * * \\
(0.173)\end{array}$ & $\begin{array}{c}1.560 * * * \\
(0.149)\end{array}$ & $\begin{array}{c}1.560 * * * \\
(0.148)\end{array}$ & $\begin{array}{c}1.560 * * * \\
(0.148)\end{array}$ \\
\hline Low-skill services & $\begin{array}{c}0.278^{* * *} \\
(0.095)\end{array}$ & $\begin{array}{c}0.608 * * * \\
(0.152)\end{array}$ & $\begin{array}{c}0.608^{* * * *} \\
(0.140)\end{array}$ & $\begin{array}{c}0.608 * * * \\
(0.140)\end{array}$ & $\begin{array}{c}0.608 * * * \\
(0.139)\end{array}$ \\
\hline Period 2: 1885-1914 & & $\begin{array}{c}0.103 \\
(0.081)\end{array}$ & $\begin{array}{c}0.714 * * * \\
(0.209)\end{array}$ & $\begin{array}{c}1.197 * * * \\
(0.376)\end{array}$ & $\begin{array}{c}0.971 * * \\
(0.406)\end{array}$ \\
\hline $\mathrm{P} 2 *$ Education sector & & $\begin{array}{c}-0.655^{* * * *} \\
(0.086)\end{array}$ & $\begin{array}{c}-0.655^{* * * *} \\
(0.122)\end{array}$ & $\begin{array}{c}-0.655^{* * * *} \\
(0.124)\end{array}$ & $\begin{array}{c}-0.655^{* * * *} \\
(0.126)\end{array}$ \\
\hline $\mathrm{P} 2 *$ Health sector & & $\begin{array}{c}-0.387 * * \\
(0.188)\end{array}$ & $\begin{array}{c}-0.387 * * \\
(0.169)\end{array}$ & $\begin{array}{c}-0.387 * * \\
(0.167)\end{array}$ & $\begin{array}{c}-0.387 * * \\
(0.167)\end{array}$ \\
\hline P2 Low-skill services & & $\begin{array}{c}-0.595 * * * \\
(0.186)\end{array}$ & $\begin{array}{c}-0.595^{* * * *} \\
(0.174)\end{array}$ & $\begin{array}{c}-0.595^{* * * *} \\
(0.175)\end{array}$ & $\begin{array}{c}-0.595 * * * \\
(0.174)\end{array}$ \\
\hline Period 1 trend & & & $\begin{array}{c}0.124 * * * \\
(0.029)\end{array}$ & $\begin{array}{c}0.135^{* * *} \\
(0.030)\end{array}$ & $\begin{array}{c}0.125^{* * * *} \\
(0.032)\end{array}$ \\
\hline Period 1 trend squared & & & $\begin{array}{c}-0.004 * * * \\
(0.001)\end{array}$ & $\begin{array}{c}-0.004 * * * \\
(0.001)\end{array}$ & $\begin{array}{c}-0.004 * * * \\
(0.001)\end{array}$ \\
\hline Period 2 trend & & & $\begin{array}{c}0.002 \\
(0.016)\end{array}$ & $\begin{array}{c}0.733 \\
(1.090)\end{array}$ & $\begin{array}{c}0.131 \\
(1.311)\end{array}$ \\
\hline Period 2 trend squared & & & $\begin{array}{l}0.000 \\
(0.000)\end{array}$ & $\begin{array}{l}-0.007 \\
(0.009)\end{array}$ & $\begin{array}{l}-0.002 \\
(0.011)\end{array}$ \\
\hline Lab-force partic. rate gaps & & & & $\begin{array}{l}-0.468 \\
(0.770)\end{array}$ & $\begin{array}{l}-0.045 \\
(0.928)\end{array}$ \\
\hline Literacy rate gaps & & & & $\begin{array}{c}-0.104 * * \\
(0.051)\end{array}$ & $\begin{array}{c}-0.124 * * \\
(0.059)\end{array}$ \\
\hline Health pub exp. (log, real) & & & & & $\begin{array}{l}-0.744 \\
(0.530)\end{array}$ \\
\hline Education pub exp. (log, real) & & & & & $\begin{array}{c}0.745 \\
(0.502)\end{array}$ \\
\hline $\begin{array}{l}\text { Constant } \\
\text { (Textile Industry. 1st year } \\
\text { Period 1) }\end{array}$ & $\begin{array}{c}0.477 * * * \\
(0.041)\end{array}$ & $\begin{array}{c}0.419 * * * \\
(0.054)\end{array}$ & $\begin{array}{l}-0.277 \\
(0.170)\end{array}$ & $\begin{array}{l}-0.127 \\
(4.054)\end{array}$ & $\begin{array}{c}2.336 \\
(5.223)\end{array}$ \\
\hline $\begin{array}{l}\text { Observations } \\
\text { Adj. R-squared }\end{array}$ & $\begin{array}{c}220 \\
0.637\end{array}$ & $\begin{array}{c}220 \\
0.694\end{array}$ & $\begin{array}{c}220 \\
0.748\end{array}$ & $\begin{array}{c}220 \\
0.749\end{array}$ & $\begin{array}{c}220 \\
0.750\end{array}$ \\
\hline \multicolumn{6}{|l|}{ Unit Root Dickey-Fuller Tests $\mathrm{a}$} \\
\hline & Z-statistic & p-value & & & \\
\hline $\begin{array}{l}\text { Textile industry } \\
\text { Education } \\
\text { Health } \\
\text { Low-skill sector }\end{array}$ & $\begin{array}{l}-3.070 \\
-1.870 \\
-2.646 \\
-2.343\end{array}$ & $\begin{array}{l}0.001 \\
0.033 \\
0.005 \\
0.011\end{array}$ & & & \\
\hline
\end{tabular}

Period 1: years 1860-1884; Period 2: years 1885-1914.

Robust standard errors in parentheses $* * * \mathrm{p}<0.01$. ** $\mathrm{p}<0.05$. $* \mathrm{p}<0.1$

a: Augmented Dickey-Fuller tests applied to the gender gap series in each sector; the null hypothesis is that the variable contains a unit root, and the alternative is that the variable was generated by a stationary process. 
well as public spending controls. In the regression analysis that follows, we split the whole period 1860-1914, identifying two subperiods: the first runs from 1860 to 1885, coinciding with the decades in which industrialization became established in the city, and the second runs from the mid-1880s to 1914 , corresponding to a period of more widespread mechanization and the introduction of steam-powered machinery into the factories. This allows for a likely structural change in the estimated coefficients.

First, in column 1 we regress the wage gap on a set of three dummy variables that take the value 1 for each of the three sectors education, health and low-skill services, and the value 0 otherwise. The left-out category in this case is the textile sector, whose average wage gap level is represented by the constant. This first specification shows that the differences stated above are indeed statistically significant at conventional levels: on average over the whole period the gender wage gap was positive in all sectors, with the health and the lowskill service sector showing statistically significant larger gaps than in the textile industry or the education sector.

In column 2, we allow wage gaps over the subperiod 1885-1914 to have a different average value in each sector of activity. To this end, we include a dummy variable that takes the value 1 for all the years of that second subperiod, and we also interact it with all the sector dummy variables. Now the constant of the model measures the average wage gap in industry during the first subperiod. The main result emerging from this second specification is that gender wage gaps in all four sectors were, on average, lower in the second period than in the first, with the exception of the textile industry, for which the difference in the second period is positive (though not significant at conventional levels). As regards the education sector, the lowest gap observed in column 1 seems to correspond entirely to a reduction that occurred in the second period, as we also noticed in Figure 3.

In column 3, we allow for different time trends within each of the two subperiods considered. The trend variable starts with a value of 0 in the first year of each subperiod, and is crossed with the dummy for each period. In this specification, the constant measures the gender wage gap in the textile sector in the first year of the first period. Our estimation results 
capture the previously observed inverted U-shape in some wage gaps during the first period, since we estimate a significant non-linear trend in wage gaps, which is positive at the beginning but declines with time until the wage gaps reach the lowest levels observed in the second period.

In column 4, we add to the specification the gender gaps in literacy rates and in labour-force participation rates (male minus female rates), and, finally, in column 5 we also include the available real per capita measures of public spending on health and education. The purpose of this is, on the one hand, to check whether the previously observed levels and trends remain robust to the inclusion of these controls into the regression, and, on the other hand, to ascertain the contribution made by these variables to explaining the gender gaps. A first observation is that the results reported above prove to be very robust to the inclusion of these gender gaps in literacy and labour-force participation rates. A second result is the statistically significant and negative correlation of the literacy gaps with the wage gaps. Thus, it could be possible that the enhanced literacy rates over the period benefit women more than men when it comes to finding better paid jobs, which could explain why the higher literacy gaps lead to lower wage gaps over the period. This result holds in column 5, where the inclusion of the public spending variables does not significantly alter any of the previously described results.

The estimated impacts of the gender gaps in literacy rates and labour-force participation rates may combine the effect derived from gender differences in these rates with different payments to men and women in response to these literacy or labour-force participation rates. In order to further disentangle these effects, we display in Table 5 the traditional Oaxaca-Blinder decomposition. Using this technique, the differences in log wages for men and women are split into a component explained by differences in characteristics that vary by gender (in our case the literacy and participation gaps) and an unexplained component (Ronald Oaxaca 1973; Alan Blinder 1973). ${ }^{7}$ The latter is taken as an estimate of the unequal pay for workers who have equal characteristics but are of a different gender. In

\footnotetext{
7 We apply the oaxaca command in Stata for the two-fold decomposition as proposed and programmed by Ben Jann 2008.
} 
our case, the dummy variables for sectors and periods are common to both the male and female samples, so the sectoral and temporal differences can only be attributed to different payments for men and women across these sectors and periods.

The results in Table 5 show that the gaps in the labour-force participation rates and literacy rates in favour of men significantly explain the positive wage gaps in their favour. The unexplained components of these two variables are negative, thus suggesting some sort of discrimination in favour of women, or, in other words, that literacy and participation rates result in pay increases higher for women than for men. These findings would thus provide support for the negative association found between literacy rates and wage gaps in Table 4 . However, the estimated standard errors of these unexplained components are high and so these estimates are not statistically significant. Finally, the different payments received by men and women across sectors and over the years of the whole analysed period match quite closely with the results previously shown in Table 4.

To sum up, our analysis of the evolution of the gender wage gaps during the period of industrialization in Alcoy indicates that the gaps were, in general, considerable but varied across sectors. Moreover, the evolution of these gaps over time reveals differences across sectors that tended to decrease in the subperiod 1885-1900 with respect to the earlier 18601884 period, before rebounding in the early years of the $20^{\text {th }}$ century. Education was an exception, as women in this sector earned wages that were notably closer to those of men. In the textile industry, the most prominent sector of economic activity in that period in Alcoy, the gender wage gap registered an inverted U-shape curve from 1860 to 1900, with the highest gender inequality appearing in the 90's. The reduction in the gaps towards the end of the $19^{\text {th }}$ century seemed to reverse in the first decade of $20^{\text {th }}$ century. The pressure exerted by the male-dominated unions, which fought against women's progress in industry in the late $19^{\text {th }}$ and early $20^{\text {th }}$ centuries, is likely to be one of the reasons. Differences in literacy rates and labour-force participation rates between men and women also help explain part of this evolution. 
Table 5.

Oaxaca-Blinder Decomposition of Gender Wage Gaps. All sectors

\begin{tabular}{|c|c|c|}
\hline & $\begin{array}{c}\text { Explained } \\
\text { (differences in } \\
\text { characteristics) } \\
\end{array}$ & Unexplained \\
\hline Lab-force partic. rate gaps & $\begin{array}{c}0.367 * * * \\
(0.096)\end{array}$ & $\begin{array}{l}-0.286 \\
(1.048)\end{array}$ \\
\hline Literacy rate gaps & $\begin{array}{c}0.401 * * * \\
(0.108)\end{array}$ & $\begin{array}{l}-1.703 \\
(1.905)\end{array}$ \\
\hline Health pub exp. (log, real) & & $\begin{array}{c}0.047 \\
(0.045)\end{array}$ \\
\hline Education pub exp. (log, real) & & $\begin{array}{c}0.130 \\
(0.101)\end{array}$ \\
\hline Period 2: 1985-1914 & & $\begin{array}{c}0.001 \\
(0.022)\end{array}$ \\
\hline Education sector & & $\begin{array}{c}0.390 * * * \\
(0.045)\end{array}$ \\
\hline Health sector & & $\begin{array}{c}0.152 * * * \\
(0.031)\end{array}$ \\
\hline Low-skill services & & $\begin{array}{c}0.743 \\
(0.476)\end{array}$ \\
\hline P2 Education & & $\begin{array}{c}-0.091 * * * \\
(0.019)\end{array}$ \\
\hline P2 Health & & $\begin{array}{c}-0.054 * * \\
(0.021)\end{array}$ \\
\hline P2 Low-skill services & & $\begin{array}{c}-0.083 * * * \\
(0.022)\end{array}$ \\
\hline Period 1 trend & & $\begin{array}{c}0.817 * * * \\
(0.229)\end{array}$ \\
\hline Period 1 trend squared & & $\begin{array}{c}-0.365^{* * *} * \\
(0.093)\end{array}$ \\
\hline Period 2 trend & & $\begin{array}{c}0.055 \\
(0.261)\end{array}$ \\
\hline Period 2 trend squared & & $\begin{array}{l}0.271^{*} \\
(0.144)\end{array}$ \\
\hline Constant & & $\begin{array}{c}0.403^{* *} \\
(0.164)\end{array}$ \\
\hline Men & \multicolumn{2}{|c|}{$\begin{array}{c}1.294 * * * \\
(0.033)\end{array}$} \\
\hline Women & \multicolumn{2}{|c|}{$0.502 * * *$} \\
\hline Difference & \multicolumn{2}{|c|}{$\begin{array}{c}0.792 * * * \\
(0.070)\end{array}$} \\
\hline Explained & & $(0.070)$ \\
\hline Unexplained & \multicolumn{2}{|c|}{$\begin{array}{c}0.024 \\
(0.048)\end{array}$} \\
\hline Observations & \multicolumn{2}{|c|}{440} \\
\hline
\end{tabular}




\section{Gender wage gaps and gender mortality gaps.}

As described in Section 2, we were able to construct an indicator of life expectancy at birth by gender in that period in Alcoy. Figure 4 shows the evolution of life expectancy by gender, showing that the so-called "female advantage" in life expectancy could also be observed in that period in Alcoy. We can distinguish three patterns over time. Up to 1875 , life expectancy rose rapidly, both for men and women. This was followed by a period, up to the end of the century, where life expectancy remained virtually constant, with a slight decline affecting women and men equally. This decline is very likely the consequence of the fairly uncontrolled economic development occurring in the city, whereby the positive economic effects of industrialization could have been offset by the accelerated industrialization and chaotic urbanization during these years.

From 1890 onwards, life expectancy returned to a path of growth, a period where the enhanced economic level of the city was accompanied by a significant increase in the percapita public health expenditure during the health reform (see Figure 1 above) and the improvements in the population's working conditions (due to the pressure of unions, leftwing political parties, social hygienists and the anarchist press; see Álvaro Soto Carmona, 1989). Overall, during the whole period 1860-1900, the life expectancy gap remained constant, with women living an average of 3.5 years more than men did. However, over the course of the early $20^{\text {th }}$ century, the differential in life expectancy of women over men increased by almost 0.5 years on average, reaching a differential of 4.5 years in 1914 (a figure that would eventually reach 5 years in 1930 , according to the available data) ${ }^{8}$

In Tables 6 and 7, we present some estimation results to highlight the relationship between the gender wage gaps in that period and the life-expectancy gaps. In this case, we define the gaps as female-to-male ratios to facilitate their interpretation as women's advantage over men. In Table 6, we estimate the female advantage in life expectancy at birth (female-to-male life expectancy ratio) following a sequential process: first, we perform the regression on the female-to-male wage ratios in the textile industry; then, we add the female-

\footnotetext{
8 Today's gender differentials in life expectancy around the world mostly range between 4 and 6 years (7 in Japan). In Spain, according to the latest official data from the World Health Organization, the difference in 2016 was 5.8 years (WHO 2016).
} 
Figure 4. Life Expectancy at Birt by Gender, Alcoy, 1860-1914

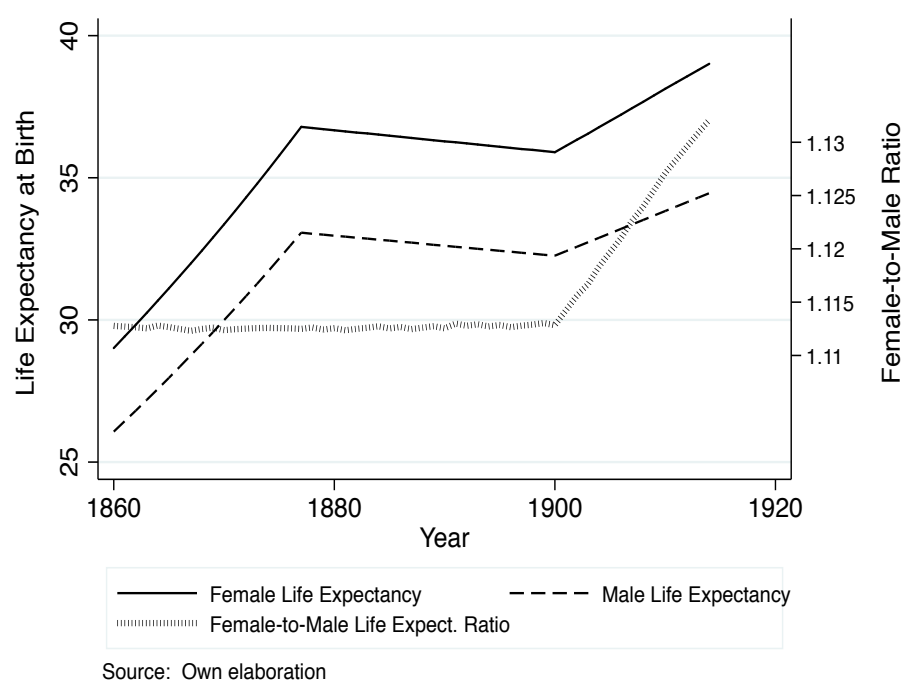

to-male participation rate and literacy rate ratios (plus the time trend and its squared value); and, finally, we add the levels of public spending on health and education. All the explanatory variables are 5-year moving average measures (averaged wages over the current plus the 4 lagged years) both to avoid simultaneity bias in the estimated effects, and to allow changes in the labour market to affect mortality with certain lags. ${ }^{9}$

The results in the first column of Table 6 suggest a positive effect of female-to-male wage ratios on the female advantage in life expectancy. In addition, the results in column 2 suggest that a reduction in the difference between women's and men's labour-force participation rate could have had a positive impact on the female longevity advantage during those years. The estimated impacts of the wage gap in industry keep the same sign although the estimated impact is now lower. This change is probably a result of the likely correlation between gender earning gaps in industry and the evolution of the labour-force participation rates, suggesting that a more/less intense involvement of women in the labour market

\footnotetext{
9 We checked for robustness with 3- and 4-year moving averages; results do not appreciably change.
} 
Table 6. Dependent variable: Female-Male Ratio of Life Expectancy Rates at Birth (OLS estimation, 5-year moving averages of explanatory variables)

\begin{tabular}{|c|c|c|c|}
\hline & $(1)$ & $(2)$ & (3) \\
\hline $\mathrm{W}^{\text {female }} / \mathrm{W}^{\text {male }}$ in Textile Industry & $\begin{array}{c}0.0111 * * * \\
(0.0019)\end{array}$ & $\begin{array}{c}0.0020 * * * \\
(0.0007)\end{array}$ & $\begin{array}{c}0.0029 * * * \\
(0.0009)\end{array}$ \\
\hline Female/Male Labour Force part. rate & & $\begin{array}{l}0.0001^{*} \\
(0.0000)\end{array}$ & $\begin{array}{c}0.0001 * * \\
(0.0001)\end{array}$ \\
\hline Female/Male Literacy rate & & $\begin{array}{c}0.0013 * * * \\
(0.0001)\end{array}$ & $\begin{array}{c}0.0013 * * * \\
(0.0001)\end{array}$ \\
\hline Health pub exp. (log, real) & & & $\begin{array}{c}0.0002 \\
(0.0002)\end{array}$ \\
\hline Education pub exp. (log, real) & & & $\begin{array}{c}-0.0008 * * * * \\
(0.0003)\end{array}$ \\
\hline Time trend & & $\begin{array}{c}-0.0005 * * * \\
(0.0000)\end{array}$ & $\begin{array}{c}-0.0013 \text { *** } \\
(0.0001)\end{array}$ \\
\hline Time trend squared & & $\begin{array}{c}0.0000 * * * \\
(0.0000)\end{array}$ & $\begin{array}{c}0.0000 * * * \\
(0.0000)\end{array}$ \\
\hline Constant & $\begin{array}{c}1.1041 * * * \\
(0.0014)\end{array}$ & $\begin{array}{c}1.1219 * * * \\
(0.0013)\end{array}$ & $\begin{array}{c}1.0641 * * * \\
(0.0048)\end{array}$ \\
\hline $\begin{array}{l}\text { Observations } \\
\text { Adj. R-squared }\end{array}$ & $\begin{array}{c}55 \\
0.4799\end{array}$ & $\begin{array}{c}55 \\
0.9256\end{array}$ & $\begin{array}{c}55 \\
0.9918\end{array}$ \\
\hline
\end{tabular}

Robust standard errors in parentheses $* * * \mathrm{p}<0.01$. ** $\mathrm{p}<0.05$. * $\mathrm{p}<0.1$

A time trend and its square was initially included, their estimated effects with p-values $<0.0000$

(particularly associated with factory jobs) negatively/positively impacted women's life conditions. Finally, the results in column 3 suggest that women's catching-up in terms of literacy correlated positively with the female life-expectancy advantage. The results are robust to the inclusion of public spending on health and education in the equation.

The measure 'life expectancy at birth' actually refers to the average number of years a newborn is expected to live if mortality patterns at the time of its birth remain constant throughout its life. To construct the measure in each period, we need to look at the number of people of different ages dying in that period, which provides a snapshot of the overall mortality characteristics for the population. Thus, changes in the mortality rates of people of different ages in the population affect the life expectancy recorded at that time.

Therefore, the effects of the industrialization process on the life expectancy measure would depend on how industrialization affected people of different ages. For example, the children or the elderly in a family unit could have been positively affected by the higher level 
of earnings entering the household thanks to the higher participation in the labour market of the adult female members; as the same time, they would not have been directly affected by the detrimental effects of working conditions. For those women actively participating in industry or other sectors of activity, the detrimental effects of working would have been more directly noticeable.

For these reasons, in Table 7 we analyse the impacts of the female-to-male gaps in wages and the rest of the covariates on the female-to-male mortality rate ratios for different ages for the population of Alcoy in that period. Gender mortality gaps are available for ten age intervals that we have aggregated into six life stages: childhood $0<5$ years, childhood $5<10$ years, childhood $10<15$ years, working-age adulthood covered by two age intervals $(25<35$ and $35<45)$ and old age $(65$ years or older). We use a finer disaggregation of the childhood age interval because, as emphasized by Bernard Harris (2001), the statistical preponderance of deaths at younger ages could obscure the relationship if treated together with ages 5 and upwards. Then, we estimate jointly a system composed of the six equations to allow the error terms, and possibly shocks, affecting mortality at all ages to be correlated.

An interesting result emerges in Table 7: the estimated signs of the coefficients change depending on the life stage we are looking at: higher female-to-male earnings ratios correlate significantly and negatively with gender mortality gaps in childhood, the correlation turns positive for the working age intervals, before becoming negative again for the 65-orolder range. The weaker and non-significant correlation for the $10<15$ years interval may be due to the fact that this interval could also include boys and girls working in the factories, and thus the effect is probably somewhere in between the effect for younger children and the effects for adults.

Hence, changes in women's earnings relative to men's during the period correlated significantly with changes in gender gaps in mortality rates. Female children and elderly women would have benefited from the higher earnings entering the household, while women of working age probably suffered a deterioration in life conditions that was reflected in a 
Table 7. Female-Male Ratio of Mortality Rates. Alcoy 1860-1914

(Regression on Female-Male Earnings Ratios)

\begin{tabular}{|c|c|c|c|c|c|c|}
\hline & $\begin{array}{l}\text { Childhood } \\
\text { (0-5 years) }\end{array}$ & $\begin{array}{r}\text { Childhood } \\
\text { (5-10 years) }\end{array}$ & $\begin{array}{r}\text { Childhood } \\
\text { (10-15 years) }\end{array}$ & $\begin{array}{c}\text { Adulthood } \\
\text { (15-35 years) }\end{array}$ & $\begin{array}{l}\text { Adulthood } \\
\text { (35-55 years) }\end{array}$ & $\begin{array}{c}\text { Old Age } \\
(55+\text { years })\end{array}$ \\
\hline $\mathrm{W}^{\text {female }} / \mathrm{W}^{\text {male }}$ in Textile Industry & $\begin{array}{l}-0.041^{*} \\
(0.024)\end{array}$ & $\begin{array}{c}-0.066^{* * * *} \\
(0.019)\end{array}$ & $\begin{array}{l}-0.036 \\
(0.029)\end{array}$ & $\begin{array}{c}0.041 * * * \\
(0.007)\end{array}$ & $\begin{array}{c}0.043 * * * \\
(0.011)\end{array}$ & $\begin{array}{c}-0.029 * * * \\
(0.009)\end{array}$ \\
\hline Female/Male Lab Force rate & $\begin{array}{c}0.005 \\
(0.003)\end{array}$ & $\begin{array}{c}0.003 \\
(0.002)\end{array}$ & $\begin{array}{c}0.001 \\
(0.004)\end{array}$ & $\begin{array}{l}-0.003 \\
(0.002)\end{array}$ & $\begin{array}{l}-0.003 \\
(0.002)\end{array}$ & $\begin{array}{c}0.001 \\
(0.001)\end{array}$ \\
\hline Female/Male Literacy rate & $\begin{array}{c}-0.020 * * * \\
(0.004)\end{array}$ & $\begin{array}{l}-0.003 \\
(0.003)\end{array}$ & $\begin{array}{c}0.046 * * * \\
(0.005)\end{array}$ & $\begin{array}{c}0.029 * * * \\
(0.001)\end{array}$ & $\begin{array}{c}0.006 * * * \\
(0.002)\end{array}$ & $\begin{array}{l}0.003^{*} \\
(0.002)\end{array}$ \\
\hline Health pub exp. (log, real) & $\begin{array}{c}-0.018^{*} \\
(0.010)\end{array}$ & $\begin{array}{l}-0.010 \\
(0.008)\end{array}$ & $\begin{array}{c}0.002 \\
(0.012)\end{array}$ & $\begin{array}{c}0.010 * * * \\
(0.003)\end{array}$ & $\begin{array}{c}0.007 \\
(0.004)\end{array}$ & $\begin{array}{l}-0.002 \\
(0.004)\end{array}$ \\
\hline Education pub exp. (log, real) & $\begin{array}{c}0.031 * * \\
(0.013)\end{array}$ & $\begin{array}{l}0.019 * \\
(0.010)\end{array}$ & $\begin{array}{l}-0.009 \\
(0.016)\end{array}$ & $\begin{array}{c}-0.022 * * * \\
(0.004)\end{array}$ & $\begin{array}{c}-0.013 * * \\
(0.006)\end{array}$ & $\begin{array}{c}0.016 * * * \\
(0.005)\end{array}$ \\
\hline Time Trend & $\begin{array}{c}-0.008 * * * \\
(0.001)\end{array}$ & $\begin{array}{c}-0.002 * * \\
(0.001)\end{array}$ & $\begin{array}{c}-0.045^{* * *} * \\
(0.001)\end{array}$ & $\begin{array}{c}-0.025^{* * *} * \\
(0.000)\end{array}$ & $\begin{array}{l}-0.001 \\
(0.001)\end{array}$ & $\begin{array}{c}0.012 * * * \\
(0.000)\end{array}$ \\
\hline Time Trend squared & $\begin{array}{c}0.000 * * * \\
(0.000)\end{array}$ & $\begin{array}{l}0.000^{*} \\
(0.000)\end{array}$ & $\begin{array}{c}0.001 * * * \\
(0.000)\end{array}$ & $\begin{array}{c}0.000 * * * \\
(0.000)\end{array}$ & $\begin{array}{c}-0.000 * * * \\
(0.000)\end{array}$ & $\begin{array}{c}-0.000 * * * \\
(0.000)\end{array}$ \\
\hline Constant & $\begin{array}{c}1.072 * * * \\
(0.261)\end{array}$ & $\begin{array}{c}0.716 * * * \\
(0.210)\end{array}$ & $\begin{array}{l}-0.528 \\
(0.321)\end{array}$ & $\begin{array}{c}0.503 * * * \\
(0.079)\end{array}$ & $\begin{array}{c}0.927 * * * \\
(0.117)\end{array}$ & $\begin{array}{c}0.337 * * * \\
(0.104)\end{array}$ \\
\hline Constant & $\begin{array}{c}55 \\
0.915\end{array}$ & $\begin{array}{c}55 \\
0.501\end{array}$ & $\begin{array}{c}55 \\
0.963\end{array}$ & $\begin{array}{c}55 \\
0.995\end{array}$ & $\begin{array}{c}55 \\
0.979\end{array}$ & $\begin{array}{c}55 \\
0.984\end{array}$ \\
\hline
\end{tabular}

Robust standard errors in parentheses $* * * \mathrm{p}<0.01, * * \mathrm{p}<0.05, * \mathrm{p}<0.1$

reduction in their mortality advantage over men during that period. These impacts on mortality differentials might be behind the observed subsequent patterns in life expectancy, with the decline in infant mortality having an important positive impact on later lifeexpectancy differentials.

As regards the role of public intervention in gender differences in life standards, we obtain estimated signs that we cannot readily interpret in all cases. At least to some extent, reverse causality may be affecting some of these results: for example, public spending on health could have risen in response to a higher incidence of disease that afflicted the population in particular years and with possible gender differences in incidence. In any case, the interest in these variables mainly lies in their use as control variables, that is, they allow us to assess whether the effects of the wage gap are mixed up with relevant unmeasured effects. 
Our results for the effects of female wages on childhood mortality are largely coherent with the hypothesis of gender discrimination in the allocation of resources inside the household, as supported by the "missing girls" anomaly documented by Beltrán and GallegoMartínez (2017 and 2018). The income-enhancing effect of the wage opportunities for women would have resulted in an alleviation of the relatively higher deprivation likely suffered by girls (Beltrán and Gallego-Martínez 2017 and 2018), with a subsequent beneficial impact on their survival. This outcome would have occurred at the expense of a higher mortality rate of working-age women.

\section{Concluding remarks}

In this paper, we have analysed gender inequalities in both wages and life expectancy in Alcoy, Spain, during the first Industrial Revolution in the $19^{\text {th }}$ century. Furthermore, we have explored the relationship between these gaps. The period under study runs from 1860 to 1914 . Our data reveal patterns in female labour-force participation and wage gaps in the textile industry that match similar documented experiences in other regions and countries, namely, high female labour-force participation and comparable wage gaps ranging from $44 \%$ to $70 \%$ on average. Somewhat different patterns were observed in sectors such as education and health, with gender wage gaps being appreciably smaller in education (female wages as high as $89 \%$ of male wages), but huge in health services (women earning no more than $17 \%$ of the male wage).

How did this economic revolution and, in particular, the role of women in that process impact female life conditions? Our results suggest that the contribution of women to household income might have favoured the female life-expectancy advantage, an effect that seems to have been channelled through a reduction in the relative mortality rates of female infants and children, at the expense of a higher mortality rate of working-age women. These findings are in line with two of the best-established hypotheses regarding the life conditions of people in that period of history: the first concerns the discrimination against and mortal neglect of girls in households during periods of severe poverty, and the second relates to the idea that the women's well-being was very adversely affected by the working conditions in the factories. 
Future research in the line opened by this paper could provide further evidence on the connection between female earnings during industrialization and the evolution of gender differentials in life expectancy. Although theories about earnings and life conditions during that period of our history have been widely discussed, the empirical documentation of the interplay between the gender gaps in these two indicators is almost non-existent. 


\section{References}

ALLEN, Robert C. 2009. The British Industrial Revolution In Global Perspective. Cambridge: Cambridge University Press.

ARACIL, Rafael, GARCÍA BONAFÉ, Mario. 1974. Industrialització al País Valencià: el cas d'Alcoi. Valencia: Eliseu Climent.

ARENAS, Carlos. 2003. Historia económica del trabajo. Madrid: Tecnos.

AUSTAD, Steven N. 2006. "Why Women Live Longer than Men: Sex Differences in Longevity". Gender Medicine, 3(2): 79-92.

BAGGE, Gosta, LUNDBERG, Erik, SVENNILSON, Ingvar. 1933. Wages, Cost of Living and National Income in Sweden, 1860-1930, Vol. II, "Wages in Sweden,". Westminster: PS King \& Son.

BARFORD, Anna, DORLING, Danny and SMITH, George Davey. 2006. "Life expectancy: Women now on Top Everywhere during 2006. Even in the Poorest Countries, Women can Expect to Outlive Men”. British Medical Journal, 332(7545): 808.

BENEITO, Àngel. 1993. Comportamiento epidémico y evolución de las causas de defunción en la comarca de l'Alcoià-El Comtat. Siglos XIX-XX. Tesis doctoral inédita.

BERG, Maxine. 1991. “Women's work and the Industrial Revolution”. ReFresh, 12.

BERG, Maxine. 1993. "What Difference Did Women's Work Make to the Industrial Revolution?". History Workshop Journal 35(1): 22-44.

BERG, Maxine and HUDSON, Pat. 1992. "Rehabilitating the Industrial Revolution". Economic History Review, 45(1): 24-50.

BELTRÁN-TAPIA, Francisco J. and GALLEGO-MARTÍNEZ, Domingo. 2017. "Where are the missing girls? Gender discrimination in 19th-century Spain". Explorations in Economic History, 66: 117-126.

BELTRÁN-TAPIA, Francisco J. and GALLEGO-MARTÍNEZ, Domingo. 2018. "What explains the missing girls in nineteenth-century Spain?”. Economic History Review, 00, 0: 1-19. 
BELTRÁN-SÁNCHEZ, Hiram, FINCH, Caleb E. and CRIMMINS, Eileen M. 2015. "Twentieth Century Surge of Excess Adult Male Mortality". Proceedings of the National Academy of Sciences, 112(29): 8993-8998.

BLAU, Francine and KAHN, Lawrence. 2017. "The gender wage gap: Extent, trends and explanations", Journal of Economic Literature, 55(3): 789-865.

BLINDER, Alan S. 1973. "Wage discrimination: reduced form and structural estimates", Journal of Human resources, 8(4): 436-455.

BORDERÍAS, Cristina. and LÓPEZ GUALLAR, Pilar. 2001. "La teoría del salario obrero y la subestimación del trabajo femenino en Ildefonso Cerdà", Quaderns del Seminari d'Història de Barcelona, 5 .

BROADBERRY, Stephen, et al. 2015. British Economic Growth, 1270-1870. Cambridge: Cambridge University Press.

BRY, Gerhard. 1960. Wages in Germany, 1871-1945. Princeton: Princeton University Press/NBER.

BURNETTE, Joyce. 1997. “An Investigation of the Female-Male Wage Gap During the Industrial Revolution in Britain”. Economic History Review, 50(2): 257-281.

BURNETTE, Joyce. 1999. "Labourers at the Oakes: Changes in the Demand for Female DayLaborers at a Farm near Sheffield During the Agricultural Revolution". Journal of Economic History, 59: 41-67.

BURNETTE, Joyce. 2008. Gender, work and wages in Industrial Revolution Britain. Cambridge: Cambridge University Press.

CAMPS, Enriqueta. 1995. La formación del mercado de trabajo industrial en la Cataluña del siglo XIX. Madrid: Ministerio de Trabajo y Seguridad Social.

CERDÁ, Enrique. 1967. Monografía sobre la industria papelera. Alcoy: Gráficas Aitana.

COMISIÓN DE REFORMAS SOCIALES. 1985 [1889-1893]. Información oral y escrita practicada en virtud de la Real Orden de 5 de diciembre de 1883. Madrid: Ed. Santiago Castillo, Edición facsímil del Centro de Publicaciones del Ministerio de Trabajo y Seguridad Social.

COX, Donald and NYE Vincent. 1989. "Male-Female Wage Discrimination in Nineteenth-Century France". Journal of Economic History, 49: 903-920. 
CUEVAS, Joaquim. 1999. Los orígenes financieros de la industria de Alcoi (1770-1900). Inedited Doctoral Thesis.

CULLEN, Mark, BAIOCCHI, Michael, EGGLESTON, Karen, LOFTUS, Pooja and FUCHS, Victor. 2016. "The Weaker Sex? Vulnerable Men and Women's Resilience to Socio-Economic Disadvantage". Population Health, 2: 512-524.

De GROOT, Gertjan. 2001. Fabricage van Verschillen. Mannenwerk, Vrouwenwerk in de Nederlandse Industrie (1850-1940). Amsterdam.

DEWERPE, Alain. 1996. Le monde du travail en France, 1800-1950. Paris: Armand Colin.

GARCÍA-GÓMEZ, José J. 2016. “Urban penalty en España: El caso de Alcoy (1857-1930)”. Historia Industrial, 63: 49-78.

GARCÍA-GÓMEZ, José J. and SALORT, Salvador. 2014. "La reforma sanitaria en Alcoi (18361914): industrialización, urbanización, fallos de mercado e intervención pública". Historia Social, 80: 95-112.

GARCÍA-GÓMEZ, José J. and ESCUDERO, Antonio. 2018. "The Standard of Living of the Workers in a Spanish Industrial City: Wages, Nutrition, Life Expectancy and Height in Alcoy (1870-1930)". Social Indicators Research, 140: 347-367.

GOLDIN, Claudia. 1990. Understanding the Gender Wage Gap: An Economic History of American Women. Oxford: Oxford University Press.

GOLDIN, Claudia. 1995. "The U-Shaped Female Labor Force Function in Economic Development and Economic History”, in T. Paul SCHULTZ (ed.), Investment in Women's Human Capital, pp. 6189. Chicago: University of Chicago Press.

GOLDIN, Claudia and LLERAS-MUNEY, Adriana. 2018. "XX>XY?: The Changing Female Advantage in Life Expectancy". NBER Working Papers Series, 24716.

GUY, Donna J. 1981. "Women, Peonage, and Industrialization: Argentina, 1810-1914”. Latin American Research Review, 16(3): 65-89.

HARRIS, Bernard. 2001. "The child is father to the man'. The relationship between child health and adult mortality in the 19th and 20th centuries". International Journal of Epidemiology, 30: 88-96.

HORRELL, Sara and HUMPHRIES, Jane. 1995. "Women's Labour Force Participation and the Transition to the Male-Breadwinner Family, 1790-1865”. Economic History Review, 48(1): 89-117.

HORRELL, Sara and HUMPHRIES, Jane. 1997. "The origins and expansion of the male breadwinner family: the case of the nineteenth-century Britain". International Review of Social History, 42: 2564. 
HUMPHRIES, Jane and SARASÚA, Carmen. 2012. "Off the Record: Reconstructing Women's Labor Force Participation in the European Past”, Feminist Economics, 18 (4): 39-67.

HUMPHRIES, Jane and SCHNEIDER, Benjamin. 2019. "Spinning the Industrial Revolution", The Economic History Review, 72(1): 126-155.

INTERNATIONAL LABOUR CONFERENCE. 1933. Employment Of Women On Underground Work In Mines Of All Kinds. Geneva: International Labour Office.

JANN, Ben. 2008. "The Blinder-Oaxaca decomposition for linear regression models". The Stata Journal, 8(4): 453-479.

JANSSENS, Angélique. 1997. "The Rise and Decline of the Male Breadwinner Family? An Overview of the Debate". International Review of Social History, 42(S5): 1-23.

JOHN, Angela V. 1984. By the Sweat of Their Brow: Women Workers at Victorian Coal Mines. London: Routledge \& Kegan Paul.

LANDES, David S. 1969. The Unbound Prometheus: Technological Change and Industrial Development in Western Europe from 1750 to the Present. Cambridge: Cambridge University Press.

MADOZ, Pascual. 1846. Diccionario Geográfico, Estadístico e Histórico de España y sus posesiones de ultramar, Tomo I, $2^{a}$ edición. Madrid: Est. Literario-Tipográfico de P. Madoz y L. Sagasti.

McKENDRICK, Neil (ed.). 1974. Historical perspectives : studies in English thought and society, in honour of J.H. Plumb. London: Europa Publications.

MOKYR, Joel. 1990. The Lever of Riches: Technological Creativity and Economic Progress. Oxford: Oxford University Press.

MUÑOZ, Luisa. 2012. "Women in the Rural and Industrial Labor Force in Nineteenth Century Spain”. Feminist Economics, 18/4: 121-143.

NADAL, Jordi. (dir.). 2003. Atlas de la industrialización de España, 1750-2000. Barcelona: Crítica.

OAXACA, Ronald. 1973. "Male-female wage differentials in urban labor markets". International Economic Review, 14(3): 693-709.

OGILVIE, Sheilagh. 2004. "Guilds, Efficiency and Social Capital: Evidence from German ProtoIndustry”. Economic History Review, 57(2): 286-333. 
PAREJO, Antonio. 2006. "De la región a la ciudad: hacia un nuevo enfoque de la historia industrial española contemporánea”. Revista de Historia Industrial, 30: 53-101.

PÉREZ CASTROVIEJO, Pedro M ${ }^{\mathrm{a}}$ 1992. Clase obrera y niveles de vida en las primeras fases de la industrialización vizcaína. Madrid: Ministerio de Trabajo y Seguridad Social.

PÉREZ FUENTES, Pilar. 1993. Vivir y morir en las minas. Estrategias familiares y relaciones de género en la primera industrialización vizcaína: 1877-1913. Bilbao: Universidad del País Vasco.

PUCHE, Javier. 2011. "Evolución del nivel de vida biológico en la Comunidad Valenciana, 18401969”. Investigaciones de Historia Económica, 7 (3): 380-394.

REAL ACADEMIA DE MEDICINA. 1879. Anales de la Real Academia de Medicina. Tomo I, Cuaderno I. Madrid: Imprenta y fundición de Manuel Tello.

REVENGA, Ricardo. 1904. La muerte en España: Un estudio estadístico sobre la mortalidad. Madrid: Prensa de Madrid.

SAN ROMÁN, Sónsoles. 2000. "La maestra española de la tradición a la modernidad". Educação \& Sociedade, 72 : 110-142.

SARASÚA, Carmen. 2018. "Women's work and structural change: occupational structure in eighteen-century Spain". Economic History Review, 00: 1-29.

SOLER, Raimon. 1997. "La evolución del salario en una empresa textil algodonera. La Fábrica de la Rambla de Vilanova i la Geltrú (1891-1925)”. Revista de Historia Económica, 2: 399-411.

SOTO CARMONA, Álvaro. 1989. El Trabajo industrial en la España contemporánea, 1874-1936. Barcelona: Anthropos.

TORRÓ, LLuís. 1994. "Los inicios de la mecanización de la industria lanera en Alcoi”. Revista de Historia Industrial, 6: 133-141.

VAZQUEZ, Enrique, CAMAÑO, Francisco, SILVI, John and ROCA, Anne. 2003. "La tabla de vida: una técnica para resumir la mortalidad y la sobrevivencia”. Boletín epidemiológico, 24 (4): 6-10.

VILAR, Margarita. 2014. "Los diferenciales salariales entre mujeres y hombres en España (c. 18501975): un análisis provisional”. Áreas, Revista Internacional de Ciencias Sociales, 33: 63-85. 
De VRIES, Jan. 1995. “The Industrial Revolution and the Industrious Revolution”. Journal of Economic History, 54(2): 249-270.

De VRIES, Jan. 2008. The Industrious Revolution: Consumer Behaviour and the Household Economy, 1650 to the Present. Cambridge: Cambridge University Press.

WORLD HEALTH ORGANIZATION. 2016. World health statistics 2016: monitoring health for the SDGs, sustainable development goals. Geneva: WHO Library Cataloguing-in-Publication Data. 